CLINICAL STUDY

\title{
High phenotypic intrafamilial variability in patients with Pendred syndrome and a novel duplication in the SLC26A4 gene: clinical characterization and functional studies of the mutated SLC26A4 protein
}

\author{
Laura Fugazzola $^{1,3}$, Valentina Cirello ${ }^{1}$, Silvia Dossena ${ }^{6}$, Simona Rodighiero ${ }^{6}$, Marina Muzza ${ }^{1}$, \\ Pierangela Castorina $^{4}$, Faustina Lalatta ${ }^{4}$, Umberto Ambrosetti ${ }^{2,5}$, Paolo Beck-Peccoz ${ }^{1,3}$, Guido Bottà ${ }^{6}$ and \\ Markus Paulmichl ${ }^{6}$ \\ Departments of ${ }^{1}$ Medical Sciences and ${ }^{2}$ Otorhinolaryngology and Ophthalmology, University of Milan, 20122 Milan, Italy, ${ }^{3}$ Endocrine and Diabetes Unit, \\ ${ }^{4}$ Medical Genetic Unit and ${ }^{5}$ Audiology Unit, Fondazione Policlinico IRCCS, 20122 Milan, Italy, ${ }^{6}$ Department of Biomolecular Sciences and Biotechnology \\ and CIMAINA, University of Milan, 20133 Milan, Italy
}

(Correspondence should be addressed to L Fugazzola; Email: l.fugazzola@policlinico.mi.it)

\begin{abstract}
Objective: Pendred syndrome (PS) is characterized by the association of sensorineural hearing loss (SNHL) and a partial iodide organification defect at the thyroid level. It is caused by mutations in the SLC26A4 gene. The encoded transmembrane protein, called pendrin, has been found to be able to transport chloride and other anions.

Design: The aim of the present study was to characterize a family with PS, which shows a strong intrafamilial phenotypic variability, including kidney atrophy in one member. The age of disease-onset was significantly different in all three affected siblings, ranging from 2 to 21 years for thyroid alterations and from 1.5 to 11 years for SNHL.

Methods: Clinical and genetic studies were carried out in affected siblings. The functional activity of the novel duplication found was studied by a fluorimetric method in a human renal cell line (HEK293 Phoenix) in which the protein was overexpressed.

Results: All three siblings were found to be compound heterozygotes for the missense mutation (1226G > A, R409H) and for a novel 11 bp duplication (1561_1571CTTGGAATGGC, S523fsX548). The latter mutation creates a frameshift leading to the loss of the entire carboxy-terminus domain. Functional studies of this mutant demonstrated impaired transport of chloride and iodide when expressed in HEK 293 Phoenix cells, when compared with wild type pendrin.

Conclusions: A novel 11 bp duplication was found in a family with Pendred syndrome, showing a high intrafamilial phenotypic variability. An impaired transmembrane anionic transport of the mutated SLC26A4 protein was demonstrated in functional studies using a heterologous cell system.
\end{abstract}

European Journal of Endocrinology 157 331-338

\section{Introduction}

In 1997, the SLC26A4 (or PDS, OMIM 605646) gene was cloned and mapped on chromosome 7q22-31.1 (1). It codes for a protein called pendrin, which is mainly expressed not only in the thyroid, inner ear, and kidney, but also in the breast, endometrium, placenta, and testis (2-7). Pendrin is thought to be composed of 12 transmembrane domains with an intracellular $\mathrm{N}$-terminus and $\mathrm{C}$ - terminus $(8,9)$. Mutations of this gene have been associated, in compound heterozygosity or in homozygosity, with Pendred syndrome (PS), an autosomal recessive disorder first described in 1896 and characterized by the association of sensorineural hearing loss (SNHL) and goiter (10). The phenotype of PS is highly variable with regard to deafness, goiter, and thyroid function (12-15). Sensorineural deafness is congenital, and in most cases has a progressive course. However, in some patients it is already severe at birth. Deafness is associated with radiologically detectable structural malformations of the inner ear. In particular, typical malformations are both an enlarged vestibular aqueduct (EVA) and an enlarged endolymphatic duct and sac (EED and EES) $(16,17)$. SNHL is a constant feature of PS, whereas goiter is observed in about $50 \%$ of the affected individuals and can vary from a slight enlargement to a large multinodular goiter, with the time of onset ranging from the first months of life until puberty. The goiter is the consequence of a partial iodide organification defect, as demonstrated by the positive perchlorate discharge test. However, the defect is only partial and most patients are euthyroid or subclinically 
hypothyroid (18). The clinical features of PS are the consequence of impairment in the function of pendrin. Indeed, in the inner ear pendrin is involved in the endolymph $\mathrm{pH}$ control and its dysfunction, owing to an altered endolymph composition, which results in an enlargement of the membranous labyrinth structures and the damage of the neuroepithelium secondary to osmotic and toxic mechanisms (3).

At the thyroid level, the role of pendrin is not clear. Some groups, including ours, gave evidence that pendrin could function as a transporter of iodide at the apical pole of the thyroid cell and its impaired function could thus lead to the iodide organification defect observed in these patients $(8,9,19-21)$. However, since the thyroid phenotype is often mild or absent, it has been hypothesized that in the absence of pendrin function, an iodide flux into the colloid space may still occur through other transport systems beside SCL26A4 or through the intervention of other genetic and environmental factors (22). Pendrin is also expressed in the kidney, where it plays a crucial role in bicarbonate secretion and in the acid-base balance besides chloride reabsorption $(4,23)$. It is reasonable to hypothesize that patients affected with PS may have disturbances of renal function, especially in the regulation of electrolytes and acid-base balance. However, no abnormalities of systemic $\mathrm{pH}$ or serum chloride levels have been reported in PS patients, possibly due to the redundancy of compensatory mechanisms in the kidney.

After cloning of the SLC26A4 gene, more than 100 different mutations have been described (http://www. medicine.uiowa.edu/pendredandbor) in patients with classical PS or affected with a non-syndromic hearing loss named familial EVA syndrome or DFNB4 and characterized by the typical inner ear malformations without thyroid abnormalities (24). The vast majority of PDS mutations involve a single nucleotide (either missense, non-sense, or splice-site). In the present study, a novel $11 \mathrm{bp}$ duplication of the SLC26A4 gene is described and functionally characterized. Interestingly, this mutation was found in compound heterozygosity in a family with an extremely variable phenotype.

\section{Materials and methods}

\section{Patients}

Patients MM, MA, and MC were born to apparently nonrelated parents who have normal hearing, no signs of hypothyroidism and no goiter. Patient MC came to our attention for pre-conceptional genetic counseling.

Patient MM, female aged 45 years, had a diagnosis of SNHL at the age of 5 years. At that time, she had normal speech. The SNHL showed a progressive worsening in the following years up to a profound hearing deficit $(80$ $\mathrm{dB})$. At 21 years of age, due to the appearance of fatigue, thyroid function was explored and a mild hypothyroidism was diagnosed, with normal free triiodothyronine (FT3) levels, slightly decreased free thyroxine (FT4) levels $(9.8 \mathrm{pmol} / \mathrm{l})$, and thyrotropin (TSH) levels above the normal range $(8.9 \mathrm{mU} / \mathrm{l})$. Thyroid ultrasound performed at the same age showed a small multinodular goiter, and the patient began L-T4 replacement treatment. Moreover, at 30 years of age, a bilateral renal atrophy was documented and the patient was submitted to right kidney transplantation at age 41 . She was also affected by secondary hyperparathyroidism and had normal IQ.

Patient MA, male aged 44, had a diagnosis of SNHL at the age of 18 months, in a prelingual period. Again, deafness showed a progressive worsening, up to a profound hearing deficit $(80 \mathrm{~dB})$. Due to the supposed diagnosis of PS in the sister, thyroid function was also evaluated in her two brothers. In patient MA, a hypothyroidism with low free thyroid hormones levels and $\mathrm{TSH}=15 \mathrm{mU} / \mathrm{l}$ was diagnosed at the age of 2 years, and L-T4 replacement treatment was started. He had a low IQ and language disturbances.

Patient MC, male aged 42, experienced the sudden appearance of a profound SNHL ( $80 \mathrm{~dB})$ at the age of 11 years. At that time, the patient had normal speech. At the age of 5 years and 4 months, the diagnosis of subclinical hypothyroidism with normal free thyroid hormones levels and elevated TSH $(8.1 \mathrm{mU} / \mathrm{l})$ was made and L-T4 replacement treatment was immediately started. Thyroid ultrasound showed a slightly enlarged gland. Patient MC had a normal IQ. None of the three patients reported symptoms suggestive of vestibular dysfunction.

\section{Clinical analyses}

Serum TSH, free T4, free T3, thyroglobulin, and antithyroglobulin/anti-thyroperoxidase antibodies levels were measured by an immunometric assay (AutoDelfia; Wallac, Turku, Finland). Normal value ranges are $0.25-4.2 \mathrm{mU} / \mathrm{l}$ for TSH, 9-20 pmol/l for FT4, and $3.8-8.0 \mathrm{pmol} / \mathrm{l}$ for FT3. In all patients, ultrasound (US) of the neck was carried out, and the thyroid volume (TV) was calculated by the ellipsoid formula.

A thyroid scintigraphy (TS) with ${ }^{123} \mathrm{I}$ and a perchlorate discharge test were performed. In particular, ${ }^{123}$ I was administered intravenously and counts were obtained at 1 and $2 \mathrm{~h}$. For the discharge test, $1 \mathrm{~g}$ of potassium perchlorate $\left(\mathrm{KClO}_{4}^{-}\right)$was administered orally and the uptake was calculated after 1,2 , and $3 \mathrm{~h}$ respectively.

In the three patients, the presence of alterations of the cochlea and of the VA was tested by high-resolution computed tomography (CT) of temporal bones in the coronal and axial planes ( $1 \mathrm{~mm}$ contiguous sections). The VA was considered enlarged when its diameter at the midpoint between the common crus and the external aperture was $1.5 \mathrm{~mm}$ or more on thin CT sections (16). High-resolution fast-spin echo (FSE) T2-weighted magnetic resonance imaging (MRI) was carried out (in axial 
and coronal planes) to study the membranous labyrinth and in particular the endolymphatic duct and sac (ED and ES). ES is rarely seen in normal subjects, despite highquality FSE MR images, and it is considered enlarged when the diameter exceeds $2.5 \mathrm{~mm}$ (17).

\section{Molecular studies}

DNA was extracted by standard methods from the whole blood of the three patients and their parents. In patient MC, all 20 coding SLC26A4 exons were amplified using primers flanking each exon, as previously described (1). The experimental studies were approved by the ethics committees of each Institution. Informed consent was obtained for all screened subjects.

\section{Functional analysis}

In order to evaluate the functional activity of the novel mutation found in the present family, the properties of pendrin transport were studied by a fluorimetric method in a human renal cell line (HEK293 Phoenix) in which the protein was overexpressed (21). To this purpose, a plasmid containing the mutated SLC26A4 sequence was generated by site-directed mutagenesis (Quik Change site-directed mutagenesis kit, Stratagene, La Jolla, CA, USA) starting from the SLC26A4 $4_{\mathrm{WT}} \mathrm{CDNA}$ previously cloned and characterized (25). The following primers were used: forward: 5'-CCTTCTTGGAATGGACTTGGAATGGCCTTGGAAGCATCCCTAGC-3', and reverse: 5'-GCTAGGGATGCTTCCAAGGCCATTCCAAGTCCATTCCAAGAAGG-3'.

Cell culture and transient transfection HEK 293 Phoenix cells were grown as previously described (21). For in vivo fluorometric chloride/iodide measurements, HEK 293 Phoenix cells were transiently transfected with wild type pendrin (pendrin ${ }_{\mathrm{WT}}$ ) or mutated pendrin showing the duplication (pendrin ${ }_{\mathrm{S} 523 \mathrm{fs} \times 548}$ ), cloned into the pIRES2-EYFP vectors; cells transfected with the empty plasmid (pIRES2-EYFP) were used as negative control. The vector used in this study allows to coexpress at the same time pendrin or its mutant as well as EYFP, by transfecting only one plasmid. The bicistronic mRNA will produce two separated proteins in the same cell; in this way, the functional integrity of the protein under study will be maintained, and the transfection efficiency will be easily determined, as the transfected cells will show yellow-green fluorescence. The day before transfection, cells were seeded in poly-Llysine-treated glass coverslip (Ø $40 \mathrm{~mm}$ ), placed into Petri dishes (Ø $60 \mathrm{~mm}$ ), and grown to $60-80 \%$ confluency. HEK 293 Phoenix cells were transfected by calcium-phosphate coprecipitation method: for each coverslip, $6 \mu \mathrm{g}$ plasmid dissolved in $162 \mu \mathrm{l}$ water were mixed with $18 \mu \mathrm{l}$ buffer A (2.5 $\left.\mathrm{M} \mathrm{CaCl}_{2}, \mathrm{pH} 5.8\right)$ and $180 \mu \mathrm{l}$ buffer B $\left(140 \mathrm{mM} \mathrm{NaCl}, 1.5 \mathrm{mM} \mathrm{Na} \mathrm{HPO}_{4}\right.$, $50 \mathrm{mM}$ HEPES, pH 7.05 adjusted with $\mathrm{NaOH})$. After incubation for 15-20 min at room temperature, the transfection mixture was spread over the cells. The experiments were performed $48 \mathrm{~h}$ after transfection.

Fluorometric analyses A fluorimetric method previously validated by our group was used to evaluate the chloride/iodide transport of SLC26A4 harboring the novel $11 \mathrm{bp}$ duplication found in the family studied in the present work (26). Briefly, since the EYFP protein is a fluorescent dye sensitive to intracellular halide amount, fluorescence is measured before and after substituting extracellular chloride with iodide. Considering that iodide is a much better EYFP quencher than chloride, an increase of intracellular iodide should lead to a decrease of the EYFP fluorescence. In particular, to evaluate the pendrin-induced halide (chloride and iodide) transport, HEK 293 Phoenix cells transiently transfected with the vector containing either pIRES2-EYFP-pendrin $_{W T}$ or the $11 \mathrm{bp}$ duplication or with the empty plasmid, were continuously perfused in a laminar-flow chamber (FCS2 System, Bioptechs Inc., Beck Road Butler, PA, USA) with 'isotonic high $\mathrm{Cl}^{-}$, $\left(2 \mathrm{mM} \mathrm{KCl}, 135 \mathrm{mM} \mathrm{NaCl}, 1 \mathrm{mM} \mathrm{MgCl} 2,1 \mathrm{mM} \mathrm{CaCl}_{2}\right.$, $10 \mathrm{mM}$ D-glucose, $20 \mathrm{mM}$ HEPES, pH 7.4, $308 \mathrm{mOsm}$ with mannitol) or 'isotonic high $\mathrm{I}^{-}$, $(2 \mathrm{mM} \mathrm{KCl}$, $135 \mathrm{mM} \mathrm{NaI}, 1 \mathrm{mM} \mathrm{MgCl} 2,1 \mathrm{mM} \mathrm{CaCl}, 10 \mathrm{mM}$ Dglucose, $20 \mathrm{mM}$ HEPES, pH 7.4, 308 mOsm with mannitol) solutions. The used iodide concentrations, which are beyond physiological iodide concentrations, were chosen to enhance fluorescence sensitivity to ion exchange. The EYFP fluorescence measurements were performed using a Leica TCS SP2 AOBS confocal microscope (Leica Microsystem, Heidelberg, Germany) with a $515 \mathrm{~nm} \mathrm{Ar/ArKr}$ laser beam for exciting the EYFP fluorescence. Traces representing fluorescence time course were obtained analyzing the regions of interest (ROI) within single cells. Measurements started after steady state conditions were reached. Maximal fluorescence variations $(\Delta \mathrm{F} \%)$ represent the maximal observed percentage difference with respect to the fluorescence intensity at the moment of the solution substitution. Statistical analysis was done by ANOVABonferroni's multiple comparison test.

\section{Results \\ Clinical data}

All patients had a normal thyroid function under L-T4 replacement treatment $(1.25,1.5$, and $1.6 \mu \mathrm{g} / \mathrm{kg} / \mathrm{day}$ for 

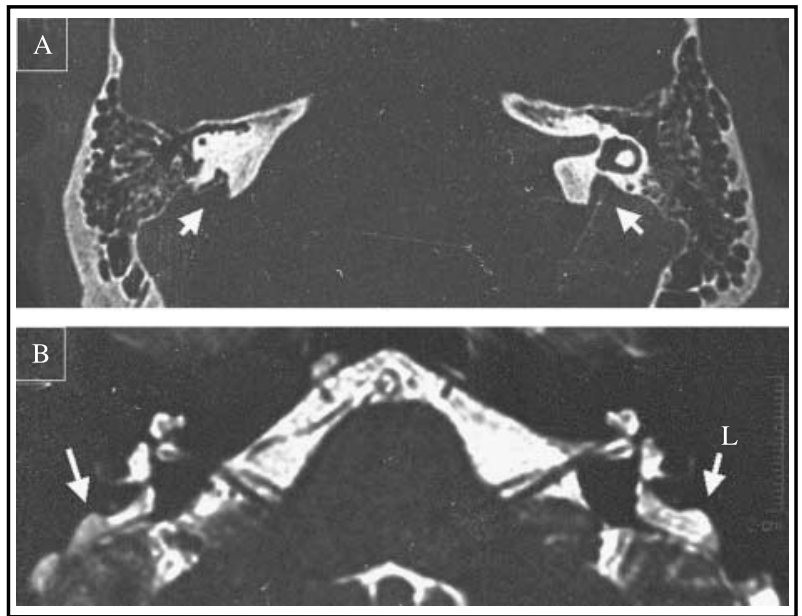

Figure 1 Radiological studies of the inner ear in patient MA. (A) CT scan of the petrous temporal bones (axial view). The vestibular aqueduct is bilaterally very enlarged (arrows). A cochlear dysplasia is also present. (B) MRI scan of the petrous temporal bones. The endolymphatic duct and sac, which are usually not visible in normal subjects, are greatly enlarged in both ears (arrows).

patient MM, MA, and MC, respectively). Anti-Tg and anti-TPO antibodies were negative in the three patients. Upon ultrasound examination, patient MM showed a small multinodular goiter $(23 \mathrm{ml})$. Patient MA had a normal TV $(7.2 \mathrm{ml})$, without echographic pattern alterations and nodules, while patient MC had a large multinodular goiter $(65.7 \mathrm{ml})$ with tracheal deviation. The perchlorate $\left(\mathrm{KClO}_{4}\right)$ test, performed by measuring radiolabeled iodide thyroid uptake before and after the oral administration of $1 \mathrm{~g}$ of $\mathrm{KClO}_{4}$, was positive in all patients with discharge rates of $40-60 \%$ of basal radioiodine uptake.

In the three siblings, malformations of the inner ear were documented. At CT scan, the VA was bilaterally enlarged, with a diameter ranging from 2 to $4 \mathrm{~mm}$. The ED and ES resulted as enlarged in all patients at MRI examination, with a ES diameter ranging from 4 to $11 \mathrm{~mm}$. Patient MA also had a dysplastic cochlea (Mondini malformation), which was not found in patients MM and MC (Fig. 1).

\section{Mutation analysis}

SLC26A4 sequence analyses showed a compound heterozygous pattern in the three patients: a known common missense mutation in exon 10 (1226 GA) and a novel $11 \mathrm{bp}$ duplication in exon 14 (1561_1571dupCTTGGAATGGC; Fig. 2). The first mutation leads to the substitution of arginine for histidine at codon 409 (R409H) and the second leads to a frameshift with the
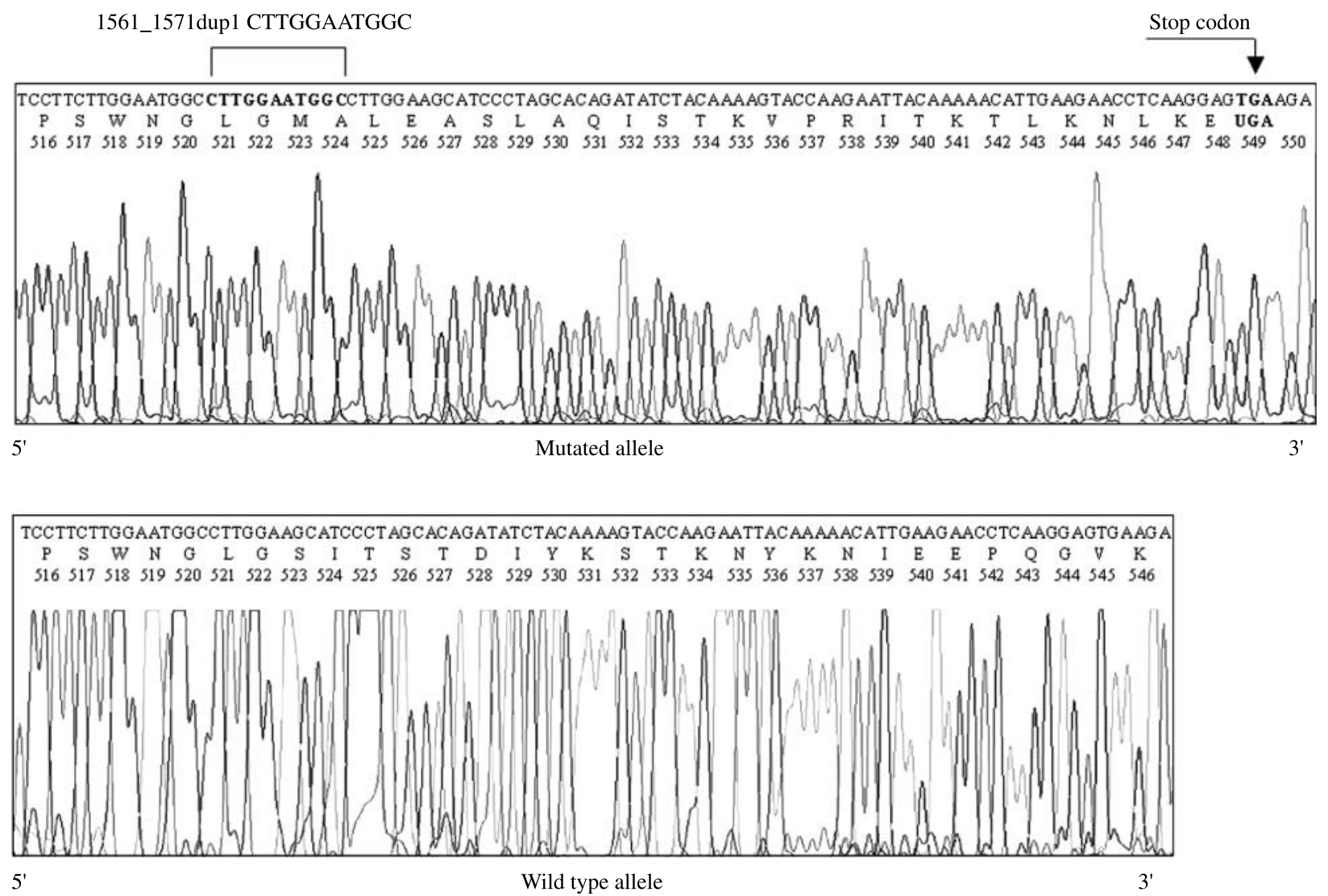

Figure 2 The sequences corresponding to a wild type and a mutated allele are reported. The nucleotide and aminoacidic sequences are also shown. 
creation of a stop codon at 548. According to the nomenclature used, the latter mutation is denoted as S523fsX 548 (27). Both mutations were inherited from the non-consanguineous parents. Whereas the mother is heterozygous for the $11 \mathrm{bp}$ duplication mutation (S523fsX548), the father is heterozygous for the missense mutation (R409H; Fig. 3).

\section{Functional analyses}

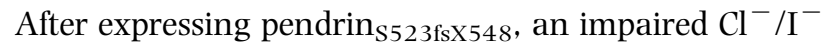
exchange can be documented in HEK 293 Phoenix cells (Fig. 4A). The intracellular fluorescence after iodide substituting for chloride in the bath solution $(135 \mathrm{mM}$ iodide instead of chloride) is decreased if wild type pendrin (pendrin ${ }_{\mathrm{WT}}$ ) is expressed. Conversely, following the same protocol, after the expression of pendrin $_{\mathrm{S} 523 \mathrm{fsX} 548}$ no decrease in fluorescence can be observed. A similar result was obtained when the empty vector was used for transfection (in both latter cases a slight increase of fluorescence can be observed instead of a decrease; Fig. 4B)

Returning to the initial conditions (i.e. $135 \mathrm{mM}$ chloride instead of iodide in the bathing solution) results in an increase in fluorescence (positive $\Delta \mathrm{F} \%$ ) for pendrin $\mathrm{WT}_{\mathrm{WT}}$ as a consequence of the diminished quenching of EYFP that follows the iodide efflux in exchange with chloride. Control and pendrin ${ }_{\text {S523fsX548 }}$ behave differently, continuing to show a slight increase in fluorescence as already observed when iodide substituted for chloride. The observed increase possibly reflects some osmotic perturbation induced by solution substitutions leading to an aspecific anion leakage and/or cell shrinkage.

\section{Discussion}

Mutations in SLC26A4 appear to be responsible for a number of overlapping clinical conditions ranging from nonsyndromic hearing loss (familial EVA syndrome or DFNB4) with widened VAs to typical PS with evident thyroid signs. The majority of SLC26A4 variants are missense substitutions, while a smaller subset consists of nonsense mutations with or without frameshift, and there are several mutations affecting splice donor or acceptor sites.

The present study reports the functional characterization of a novel $11 \mathrm{bp}$ duplication (resulting in S523fsX548), which was found in compound heterozygosity with a missense mutation leading to substitution of $\mathrm{R} 409 \mathrm{H}$. This duplication creates a frameshift with stop codon at 548 and the deriving truncated protein lacks the entire carboxy-terminus

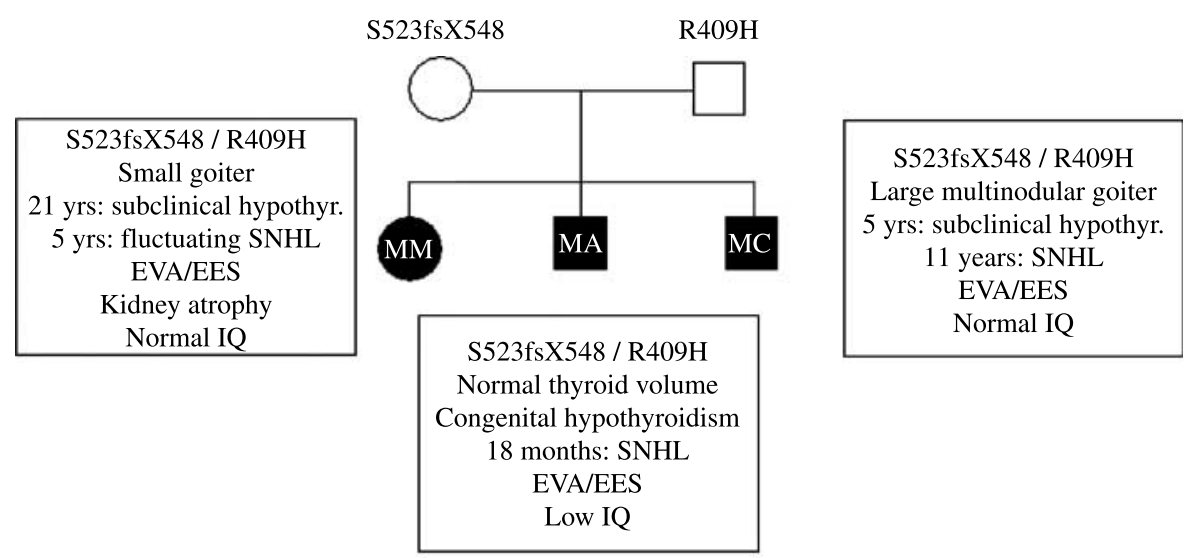

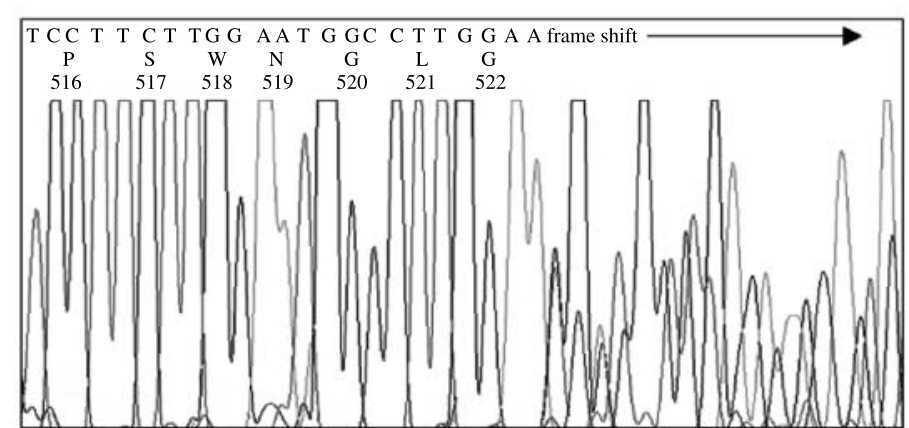

1561_1571dupCTTGGAATGGC leading to a truncated protein with loss of the $\mathrm{C}$-terminus domain (S523fsX548)
Figure 3 Clinical and molecular features of the present Pendred syndrome family. Affected members are indicated as black symbols. The age of onset of thyroid and inner ear alterations are indicated. Electropherogram corresponds to SLC26A4 11 bp duplication identified in compound heterozygosity in the three affected siblings and in heterozygosity in the unaffected mother. 


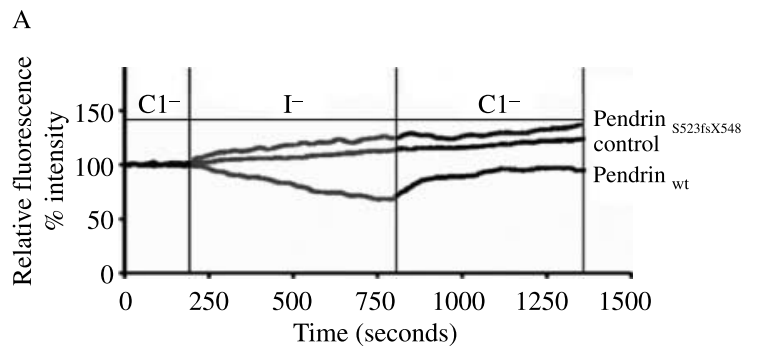

B

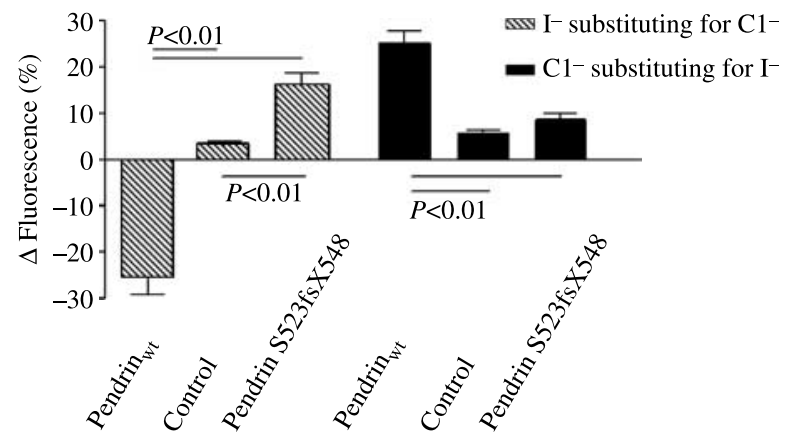

Figure 4 HEK 293 Phoenix cells expressing pendrin ${ }_{5523 f s \times 548}$ have an impaired $\mathrm{I}^{-}$transport. (A) Relative fluorescence intensity values were obtained analyzing the ROI within single cells transfected with pIRES2-EYFP-pendrin ${ }_{\mathrm{WT}}(n=7)$, pIRES2-EYFP- pendrin $_{\mathrm{S} 523 \mathrm{fs} \times 548}$ $(n=8)$, or the empty $(n=16)$ plasmids and exposed to the 'high $\mathrm{Cl}^{-}$, or the 'high l-' solutions. Cells transfected with

pendrin $_{\text {S523fs } \times 548}$ serve as the control cells. At the top of each column, the respective changes of the extracellular solutions (isotonic high $\mathrm{Cl}^{-}$or isotonic high I${ }^{-}$) are indicated. (B) Maximal fluorescence \% variation after the ionic substitution is calculated as the average of different ROI inside the cells (pendrin ${ }_{\mathrm{WT}} n=7$; pendrin $_{5523 f_{s} \times 548} n=8$, empty vector $\left.n=16\right)$. In every panel, the maximal fluorescence variation of the pendrin $\mathrm{WT}_{\mathrm{WT}}$ is significantly different from the pendrin ${ }_{5523 f_{s} \times 548}$ and the empty vector (calculated by ANOVA-Bonferroni's multiple comparison test).

domain. Indeed, functional studies demonstrated an impaired transport of chloride and iodide in HEK 293 Phoenix cells expressing S523fsX548 when compared with pendrin $_{\mathrm{WT}}$. In particular, after exchanging extracellular chloride for the same amount of iodide and viceversa, in cells expressing pendrin ${ }_{\mathrm{WT}}$ the EYFP fluorescence variations were rapid and reversible, contrary to what was observed for both pendrin ${ }_{\mathrm{S} 523 \mathrm{fsX} 548}$ and control. These data are consistent with the phenotype observed in the respective patients. The missense mutation $\mathrm{R} 409 \mathrm{H}$ has been associated with PS in several cohorts and has been shown to impair pendrin function (28-31), in agreement with the phenotype resulting from the compound heterozygosis described in the affected members.

The present family is of particular interest, since it displays a high phenotypic variability. Indeed, despite the presence of major inner ear malformations responsible for a profound SNHL, the age of onset and the progression of deafness were significantly different in the three patients tested. Patient MM had the first diagnosis of SNHL at age 5 with a progressive worsening in the following years up to a profound deficit, and patient MA was diagnosed with SNHL at 18 months and also showed a progressive worsening up to a profound hearing deficit. In contrast, patient MC experienced the sudden appearance of a profound SNHL at the age of 11 . All three siblings had a comparable degree of EVA, excluding the hypothesis that the severity of the inner ear malformation could be a major determinant of the observed variability. Similarly, the diagnosis of hypothyroidism was made during childhood in the two male patients and at age 21 for their sister. The respective TVs range from normal (MA) to large multinodular goiters (MC). Interestingly, patient MM suffers from a renal disease and has been submitted to kidney transplantation and patient MA has a low IQ and language disturbances despite early start of replacement therapy at the diagnosis of subclinical hypothyroidism.

Intrafamilial and interfamilial phenotypic variability, mostly in terms of presence/absence and severity of thyroid and inner ear malformations, have been reported by other groups $(12-14,32)$. In the family tested in the present work, the extreme variability can not only be found in the degree of hearing impairment, but also in the time of onset for the thyroid alterations. Moreover, the evidence of a renal dysfunction in one patient is particularly interesting because this alteration in PS is seldom seen, however expected, since the SLC26A4 transporter is involved in kidney acid-base regulation and blood volume maintenance (33-35). However, no evidence exists about a direct cause-effect relationship between impaired pendrin function and kidney atrophy, and this finding could be a mere coincidence. The reason why the three tested family members suffering from PS show this pronounced phenotypic variability is unknown. The degree of iodide deficiency has been supposed to be a modifying factor in PS (36), but other environmental or genetic factors are also likely to be involved. These include the action of modifier genes that indeed have been demonstrated to play an important role in disease variability in other autosomal disorders (37).

In conclusion, the identification of novel complex mutation expands the spectrum of mutations in the SLC26A4 gene. The impairment of chloride and iodide transport recorded for the mutant further supports the hypothesis that pendrin could play a crucial role in iodide transport from the thyroid cell to the colloid. The clinical studies on the present family confirm that the PS phenotype is extremely variable, both for the degree of impairment and the time of onset, the inner ear malformations being the only constant phenotypic feature.

\section{References}

1 Everett LA, Glaser B, Beck JC, Idol JR, Buchs A, Heyman M, Adawi F, Hazani E, Nassir E, Baxevanis AD, Sheffield VC \& Green ED. Pendred syndrome is caused by mutations in a putative sulphate transporter gene (PDS). Nature Genetics 199717 411-422. 
2 Bidart JM, Mian C, Lazar V, Russo D, Filetti S, Caillou B \& Schlumberger M. Expression of pendrin and the Pendred syndrome (PDS) gene in human thyroid tissue. Journal of Clinical Endocrinology and Metabolism $2000 \mathbf{8 5} 2028-2033$.

3 Everett LA, Morsli H, Wu DK \& Green ED. Expression pattern of the mouse ortholog of the Pendred's syndrome gene (Pds) suggests a key role for pendrin in the inner ear. PNAS $1999969727-9732$.

4 Royaux IE, Wall SM, Karniski LP, Everett LA, Suzuki K, Knepper MA \& Green ED. Pendrin, encoded by the Pendred syndrome gene, resides in the apical region of renal intercalated cells and mediates bicarbonate secretion. PNAS 200198 4221-4226.

5 Rillema JA \& Hill MA. Prolactin regulation of the pendrin-iodide transporter in the mammary gland. American Journal of Physiology. Endocrinology and Metabolism 2003284 E25-E28.

6 Suzuki K, Royaux IE, Everett LA, Mori-Aoki A, Suzuki S, Nakamura K, Sakai T, Katoh R, Toda S, Green ED \& Kohn LD. Expression of PDS/Pds, the Pendred syndrome gene, in endometrium. Journal of Clinical Endocrinology and Metabolism 200287938.

7 Lacroix L, Mian C, Caillou B, Talbot M, Filetti S, Schlumberger M \& Bidart JM. $\mathrm{Na}(+) / \mathrm{I}(-)$ symporter and Pendred syndrome gene and protein expressions in human extra-thyroidal tissues. European Journal of Endocrinology 2001144 297-302.

8 Royaux IE, Suzuki K, Mori A, Kato R, Everett LA, Kohn LD \& Green ED. Pendrin, the protein encoded by the Pendred syndrome gene (PDS), is an apical porter of iodide in the thyroid and is regulated by thyroglobulin in FRTL-5 cells. Endocrinology 2000 $141839-845$.

9 Gillam MP, Sidhaye AR, Lee EJ, Rutishauser J, Stephan CW \& Kopp P. Functional characterization of pendrin in a polarized cell system. Evidence for pendrin-mediated apical iodide efflux. Journal of Biological Chemistry 2004279 13004-13010.

10 Pendred V. Deaf-mutism and goiter. Lancet 189611532.

11 Lopez-Bigas N, Rabionet R, de Cid R, Govea N, Gasparini P, Zelante L, Arbones ML \& Estivill X. Splice-site mutation in the PDS gene may result in intrafamilial variability for deafness in Pendred syndrome. Human Mutation 199914 520-526.

12 Masmoudi S, Charfedine I, Hmani M, Grati M, Ghorbel AM, Elgaied-Boulila A, Drira M, Hardelin JP \& Ayadi H. Pendred syndrome: phenotypic variability in two families carrying the same PDS missense mutation. American Journal of Medical Genetics $20009038-44$.

13 Campbell C, Cucci RA, Prasad S, Green GE, Edeal JB, Galer CE, Karniski LP, Sheffield VC \& Smith RJ. Pendred syndrome, DFNB4, and PDS/SLC26A4 identification of eight novel mutations and possible genotype-phenotype correlations. Human Mutation 2001 17 403-411.

14 Napiontek U, Borck G, Muller-Forell W, Pfarr N, Bohnert A, Keilmann A \& Pohlenz J. Intrafamilial variability of the deafness and goiter phenotype in Pendred syndrome caused by a T416P mutation in the SLC26A4 gene. Journal of Clinical Endocrinology and Metabolism 200489 5347-5351.

15 Blos H, Feldmann D, Duval V, Messaz O, Denoyelle F, Loundon N, Sergout-Allaoui A, Houang M, Duriez F, Lacombe D, Delobel B, Lema J, Catros H, Journel H, Doruin-Garraud V, Obstoy MF, Toutain A, Odent S, Toublanc JE, Couderc R, Petit C, Garabedian EN \& Marlin S. Screening of SLC26A4 (PDS) gene in Pendred's syndrome: a large spectrum of mutations in France and phenotypic heterogeneity. Clinical Genetics $200466333-340$.

16 Phelps PD, Coffey RA, Trembath RC, Luxon LM, Grossman AB, Britton KE, Kendall-Taylor P, Graham JM, Cadge BC, Stephens SGD, Pembrey ME \& Reardon W. Radiological malformations of the ear in Pendred syndrome. Clinical Radiology 1998 $53268-273$

17 Fugazzola L, Mannavola D, Cerutti N, Maghnie M, Pagella F, Bianchi P, Weber G, Persani L \& Beck-Peccoz P. Molecular analysis of the Pendred's syndrome gene and magnetic resonance imaging studies of the inner ear are essential for the diagnosis of true Pendred' syndrome. Journal of Clinical Endocrinology and Metabolism $2000 \mathbf{8 5} 2469-2475$.
18 Fugazzola L, Cerutti N, Mannavola D, Vannucchi G \& BeckPeccoz P. The role of pendrin in iodide regulation. Experimental and Clinical Endocrinology and Diabetes 2001109 18-22.

19 Scott DA, Wang R, Kreman TM, Sheffield VC \& Karnishki LP. The Pendred syndrome gene encodes a chloride-iodide transport protein. Nature Genetics 199921 440-443.

20 Wolff J. What is the role of Pendrin? Thyroid 200515 346-348.

21 Dossena S, Vezzoli V, Cerutti N, Bazzini C, Tosco M, Sironi C, Rodighiero S, Meyer G, Fasci U, Furst J, Ritter M, Fugazzola L, Persani L, Zorowka P, Storelli C, Beck-Peccoz P, Bottà G \& Paulmichl M. Functional characterization of wild-type and a mutated form of SLC26A4 identified in a patient with Pendred syndrome. Cellular Physiology and Biochemistry $2006 \quad 17$ 245-256.

22 Taylor JP, Metcalfe RA, Watson PF, Weetman AP \& Trembath RC. Mutations of the PDS gene, encoding pendrin, are associated with protein mislocalization and loss of iodide efflux: implications for thyroid dysfunction in Pendred syndrome. Journal of Clinical Endocrinology and Metabolism 200287 1778-1784.

23 Soleimani M, Greeley T, Petrovic S, Wang Z, Amlal H, Kopp P \& Burnham CE. Pendrin: an apical $\mathrm{Cl}^{-} / \mathrm{OH}^{-} / \mathrm{HCO}_{3}^{-}$exchanger in the kidney cortex. American Journal of Physiology. Renal Physiology 2001280 F356-F364.

$24 \mathrm{Li}$ XC, Everett LA, Lalwani AK, Desmukh D, Friedman TB, Green ED \& Wilcox ER. A mutation in PDS causes non-syndromic deafness. Nature Genetics 199818 215-217.

25 Dossena S, Maccagni A, Vezzoli V, Bazzini C, Garavaglia ML, Meyer G, Furst J, Ritter M, Fugazzola L, Persani L, Zorowka P, Storelli C, Beck-Peccoz P, Bottà G \& Paulmichl M. The expression of wild-type pendrin (SLC26A4) in human embryonic kidney (HEK 293 Phoenix) cells leads to the activation of cationic currents. European Journal of Endocrinology 2005153 693-699.

26 Dossena S, Rodighiero S, Vezzoli V, Bazzini C, Sironi C, Meyer G, Furst J, Ritter M, Garavaglia ML, Fugazzola L, Persani L, Zorowka P, Storelli C, Beck-Peccoz P, Bottà G \& Paulmichl M. Fast fluorimetric method for measuring pendrin (SLC26A4) Cl/I transport activity. Cellular Physiology and Biochemistry 200618 67-74.

27 den Dunnen JT \& Antonarakis E. Nomenclature for the description of human sequence variations. Human Genetics $2001 \mathbf{1 0 9}$ 121-124.

28 Fugazzola L, Cerutti N, Mannavola D, Crinò A, Cassio A, Gasparoni P, Vannucchi G \& Beck-Peccoz P. Differential diagnosis between Pendred's and 'pseudo-Pendred's' syndromes: clinical, radiological and molecular studies. Pediatric Research $2002 \mathbf{5 1}$ 479-484.

29 Bogazzi F, Russo D, Raggi F, Ultimieri F, Berrettini S, Forli F, Grasso L, Ceccarelli C, Mariotti S, Pinchera A, Bartalena L \& Martino E. Mutations in the SLC26A4 (pendrin) gene in patients with sensorineural deafness and enlarged vestibular aqueduct. Journal of Endocrinological Investigation 200427 430-435.

30 Van Hauwe P, Everett LA, Coucke P, Scott DA, Kraft ML, RisStalpers C, Bolder C, Otten B, de Vijlder JJ, Dietrich NL, Ramesh A, Srisailapathy SC, Parving A, Cremers CW, Willems PJ, Smith RJ, Green ED \& Van Camp G. Two frequent missense mutations in Pendred syndrome. Human Molecular Genetics $1998 \quad 7$ 1099-1104.

31 Gillam MP, Bartolone L, Kopp P \& Benvenga S. Molecular analysis of the PDS gene in a nonconsanguineous Sicilian family with Pendred's syndrome. Thyroid 200515 734-741.

32 Reardon W, Coffey R, Phelps PD, Luxon LM, Stephens D, KendallTaylor P, Britton KE, Grossman A \& Trembath R. Pendred syndrome: 100 years of underascertainment? Quarterly Journal of Medicine $199790443-447$.

33 de Seigneux S, Malte H, Dimke H, Frokiaer J, Nielsen S \& Frische S. Renal compensation to chronic hypoxic hypercapnia: downregulation of pendrin and adaptation of the proximal tubule. American Journal of Physiology. Renal Physiology $2007 \mathbf{2 9 2}$ F1256-F1266.

34 Pech V, Kim YH, Weinstein AM, Everett LA, Pham TD \& Wall SM. Angiotensin II increases chloride absorption in the cortical 
collecting duct in mice through a pendrin-dependent mechanism. American Journal of Physiology. Renal Physiology 2007292 F914-F920.

35 Soleimani M \& Xu J. SLC26 chloride/base exchangers in the kidney in health and disease. Seminars in Nephrology 200626 375-385.

36 Kopp P, Karamanoglu Arseven O, Sabacan L, Kotlar T, Dupuis J, Cavaliere H, Santos CLS, Jameson JL \& Medeiros-Neto G. Phenocopies for deafness and goiter development in a large inbread brazilian kindred with Pendred's syndrome associated with a novel mutation in the PDS gene. Journal of Clinical Endocrinology and Metabolism 199984 336-341.
37 Zielenski J, Corey M, Rozmahel R, Markiewicz D, Aznarez I, Casals T, Larriba S, Mercier B, Cutting GR, Krebsova A, Macek M Jr, Langfelder-Schwind E, Marshall BC, DeCelie-Germana J, Claustres M, Palacio A, Bal J, Nowakowska A, Ferec C, Estivill X, Durie P \& Tsui LC. Detection of a cystic fibrosis modifier locus for meconium ileus on human chromosome 19q13. Nature Genetics 199922 128-129.

Received 20 April 2007

Accepted 26 June 2007 